\title{
IMPLIKASI COVID-19 TERHADAP KEMISKINAN KANAK-KANAK
}

\author{
FARRAH ATIKAH SAARI* \\ WAN AHMAD AMIR ZAL WAN ISMAIL** \\ TENGKU FAUZAN TENGKU ANUAR*** \\ atikah.s@umk.edu.my*,waamirzal@umk.edu.my**,tengkufauzan@umk.edu.my***
}

\begin{abstract}
Abstrak
Isu kemiskinan kanak-kanak amat jarang diwacanakan di Malaysia sedangkan ia merupakan isu kritikal yang menjadi penentu masa hadapan mereka dan negara. Keadaan kemiskinan kanak-kanak menjadi lebih teruk dengan penularan wabak Covid-19 dan pengisytiharan Perintah Kawalan Pergerakan (PKP). Andaian awal, PKP memberikan kesan secara multidimensional ke atas kemiskinan kanak-kanak. Justeru, objektif kajian adalah untuk mengetahui cabaran berkaitan implikasi Covid-19 yang berbentuk multidimensional ke atas kemiskinan kanak-kanak. Kajian menggunapakai pendekatan kualitatif dengan merujuk kepada sumber sekunder sahaja yang terdiri dari Laporan Kemiskinan Kanak-kanak Bandar, UNICEF 2017, artikel jurnal, buku dan tesis yang berkaitan. Pengkaji menggunakan instrument melalui pendekatan Cadangan Dasar Program sedia ada yang dikeluarkan oleh United Nations Children's Fund (UNICEF Malaysia) yang meliputi empat bidang iaitu pendidikan, makanan, kesihatan dan kebajikan. Hasil kajian mendapati bahawa implikasi Covid-19 sememangnya telah memberi pelbagai kesan negatif kepada kanak-kanak dalam pendidikan, makanan, kesihatan dan kebajikan. Kesimpulannya, kajian ini telah membantu pelbagai pihak, khususnya pihak kerajaan berkaitan realiti kesan Covid-19 dan PKP ke atas kemiskinan kanak-kanak dari pelbagai dimensi.
\end{abstract}

Kata Kunci: implikasi, isu, kanak-kanak, kemiskinan, multidimensi

* Pensyarah di Fakulti Teknologi Kreatif dan Warisan, Universiti Malaysia Kelantan, Malaysia.

** Pengarah di Institut Penyelidikan \& Pengurusan Kemiskinan / Pusat Pengajian Bahasa Dan Pembangunan Insaniah, Universiti Malaysia Kelantan, Malaysia.

*** Pensyarah Kanan di Fakulti Teknologi Kreatif dan Warisan, Universiti Malaysia Kelantan, Malaysia. 


\title{
THE IMPLICATION OF COVID-19 TOWARDS THE POVERTY IN CHILDREN
}

\author{
FARRAH ATIKAH SAARI* \\ WAN AHMAD AMIR ZAL WAN ISMAIL** \\ TENGKU FAUZAN TENGKU ANUAR***
}

atikah.s@umk.edu.my*,waamirzal@umk.edu.my**,tengkufauzan@umk.edu.my***

\begin{abstract}
The poverty issue among children is rarely being discussed and talked about in Malaysia while it is one critical problem that could affect the future generation as well as the nation. The poverty rate among children has increased with the outbreak of the Covid-19 pandemic and also the declaration of Restricted Movement Order (RMO). Based on the early estimation, RMO has been affecting the children's poverty in multidimensional aspects. Hence, objective of the study is to know the challenges related to the Covid-19 implications in form of multidimensional aspects regarding the children poverty. The research is using a qualitative approach by referring to the secondary resources which is the Report of Poverty in Urban Kids, UNICEF 2017, journal articles, books, and theses. Researchers use the instrument through the existing Program Policy Proposal approach issued by the United Nations Children's Fund (UNICEF Malaysia) which covers four areas, education, food, health and welfare. The results of the study found that the implications of Covid-19 have indeed had various negative effects on children in education, food, health and welfare. In conclusion, this study has helped various parties, especially the government bodies on tackling the reality of Covid-19 and RMO towards the poverty of children in multidimensional aspects.
\end{abstract}

Keywords: children, implications, issues, multidimensional, poverty

** Director at Institute of Research and Poverty Management/ Faculty of Language Studies and Human Development, Universiti Malaysia Kelantan, Malaysia.

*** Senior Lecturer at Faculty of Creative Technology and Heritage, Universiti Malaysia Kelantan. Malaysia. 
Children are defined as an individual under 18 years old as recorded in the Children Act 2001 based on the Report of Urban Children Poverty, UNICEF 2017. Poverty in children is an issue that is rarely discussed in Malaysia while this issue is considered critical as it could affect the children's future in the long term. Based on Begum et al,. (2012), children poverty is identified or understood as a situation where the children are living in a household with a family income at less than one dollar per day. According to the World Bank, the children poverty applies to any children who live in a household income lower than a line of poverty. Both definitions are based on the financial elements that do not represent the whole issue and not describe the reality of poverty in children. This is a different case with the definition according to Ingutia et al (2020), where the children poverty is understood as those whom their rights are denied in getting access to proper supports in term of material, sociocultural, economy, politic, social and environments which are the basic things needed for the children development. This definition describes the issue more adequately because it considers the surrounding elements of the children in poverty.

With the current unfortunate situation due to the Coronavirus's pandemic or popularly known as COVID-19, Malaysia's government has taken some actions by declaring the Restricted Movement Order (RMO). This measure was taken to cut off the infection chain of COVID-19 as reduce the risk for more potential infections among the citizens. RMO limits the movement and involves other activities, including educational, social, and economic aspects. Especially from the economical aspect, based on Jabatan Perangkaan Malaysia (2020) research, it is estimated 52.6\% Malaysians are affected due to RMO especially among them who work as freelancers or contract based. These RMO impacts could also contribute to the children's poverty directly due to affected family income. When their family income is affected, it will also negatively influence the children's development, welfare, education, and nutrition (Ge \& Wang, 2019) which then contribute to a long-term effect. According to Ingutia, Rezitis, and Sumelius (2020), with insufficient resources and unacceptable conditions, in terms of nutrition and facilities in the community or family, the children will have difficulties in exploring their potentials. Besides, they also have a high probability of dropping school and paying less attention to learning and education (Ingutia et al., 2020). Poverty also creates a boundary and gap with the children who are not in the poverty category, hence, further denying them from the established system, (Qi \& Wu, 2015). Thus, in the context of RMO, it directly threatens the children's potentials of the children in poverty from various angles.

The RMO announcement can be considered as a sudden action because many parties are not expecting that this measure will be carried out. This sudden move directly affects the poor children and their families and the support institution system. Based on Cuesta and Meyer (2018), to solve the poverty in children, the authority should also take the responsibility to provide an exclusive system to take them out of the poverty state. These bodies usually provide a professional and exclusive system to enhance the environment in a multidimensional aspect for the children strengthen the economic and social aspects (Ge \& Wang, 2019). However, when the RMO was implemented, there are concerns about the institution's vulnerabilities related to poverty children. Furthermore, poverty positioned the children to be in a inadequate and improper 
environment and condition. According to Chaudry and Wimer (2016), poverty caused many sufferings from various financial problems in getting sufficient basic requirements, education, nutrition, and welfare. As a result, this situation forces them to miss many opportunities and will be left behind from many aspects, making them unable to catch up with the mainstream system (Main, 2017). Within this RMO situation, the children's poverty problem will become more severe. This issue needs a multidimensional analysis to ensure some practical solutions for the children in the long-term.

\subsection{Issues and Challenges}

The rapid outbreak of Covid-19 is worrying everyone and hence, Kelantan's government has been providing incentives worth RM300 per one B40 family with positive-tested Coronavirus (Covid-19). Based on Minister, Datuk Ahmad Yakob, RM300 will be under the monitoring centre for Covid-19. Meanwhile, finance support worth RM500 will be given to the family members of the COVID-19-infected deceased who not a member of the Kifaalah scheme of Kelantan state government. RM5 million was allocated to deal with the Covid-19 outbreak hoping to reduce the burden of the Kelantan's citizens. The allocation could also manage and reducing the burden of the less fortunate citizens affected by the Covid-19 (Berita Harian Online, 2020). With those financial supports, it can at least impact the welfare of the children in every household. We do not know how far it can give positive impacts on the children's needs during this pandemic. However, Malaysia has proved its success in enhancing the citizen condition with a steady growth of its economy within five decades in which KDNK recorded a $10 \%$ increase per year since the 70 s. On average, KDNK growth established a high-income rate for households and it continues to inspire efforts in reducing the poverty rate. The poverty rate has reduced significantly, which is from $50 \%$ in 1970 to $0.4 \%$ in 2016 . Even though the national poverty rate is $0.4 \%$, poverty still exists. Based on the data provided by UNICEF Malaysia, $34 \%$ of indigenous people in Peninsular Malaysia live in poverty while $20.2 \%$ of Sabah indigenous society and $7.3 \%$ of Sarawak's in a state of poverty (UNICEF Malaysia, 2018). Hence, ongoing research is crucial and needs to be carried out to observe the COVID-19 implications on children during the pandemic because the success in economic growth can be measured through how far the children could benefit from it. If such a developmental plan is sustainable, it must be fair in approaching every potential child and guarantee their promising future during and after the Covid-19 pandemic.

A children protection policy is required during the Covid-19 pandemic to encourage each agency, organization, and society in giving attention to the protection of the children and carry out the responsibility together (Ge \& Wang, 2019). This policy is in line with the Convention's philosophy regarding the Children Rights and Children Policy 2001 that emphasizes the principle of protection on children to ensure their best interest, which was also established in the National Children Protection Policy 2001. Some parents stated that they are more worried about Covid-19 than the problem in managing their families at homes which indirectly might affect the children (Portal Jabatan Kebajikan Masyarakat, Dasar Perlindungan Kanak-kanak Negara 2001). Plus, children are the future hope and the source of human capital for the nation. This human capital could be developed by providing a safe and conducive environment. Furthermore, protection of the children against neglect in education, nutrition, health, 
and welfare must be prioritized especially during the pandemic of Covid-19. Based on the statistic data by UNICEF Malaysia, about $4 \%$ of households receiving financial support from zakat or JKM (Jabatan Kebajikan Masyarakat) meanwhile 34\% of households with income under RM4000 were not qualified to accept BRIM, and $77 \%$ households were recorded to not have any savings. These supports and savings could affect the wellbeing of the children especially while facing the pendemic outbreak. Based on (Haq \& Zia, 2013; OECD, 2019 'Thomson \& Aked, 2009), a subjective wellbeing indicator for children is closely related to their feelings and thoughts where this measurement could also involve perception, feelings, and experience (Camfield et al., 2008). Positive well-being can also be understood or defined as their feeling regarding material, family, health, academics, and other life aspects (Statham \& Chase, 2010). Besides, an indicator for the children's well-being is often related to their requirement in the family relationship, morale, psychosocial, spiritual, and participation in social activities. Thus, this research is crucial to understand the parents' perceptions towards the children's needs in the aspects of education, nutrition, health, welfare and its impacts during the COVID-19 outbreak.

These children are also part of society who can't escape the impacts of this lifethreatening Covid-19 outbreak that happening globally. The world was shocked by the news of an 11 years old girl infected by Covid-19 in East Jawa, Indonesia. Hence, various agencies have been involved to help any affected community in name of humanity as stated by Allah SWT: "O ye who believe! Seek help with patient perseverance and prayer; for Allah is with those who patiently persevere (Chapter AlBaqarah: 153) Allah SWT explained that the best way to ask for Allah's help when people are facing many difficulties (some are the difficulties in life such as disease outbreak or any disaster) is through patient and prayer. The charities contributed by several agencies worth RM42,339,100 were distributed to the asnaf group is the most significant amount distributed by the Kelantan government. This financial assistance was given in cash worth RM400 or RM200 per month by bank account transfer method. About 9775 receivers of Monthly Poverty Aid worth RM400 were recorded until December 2019 while for RM200 support, about 270 receivers were recorded that makes a total of 10,045 receivers. This allocation has been distributed before the Covid-19 outbreak and is still ongoing until now.

From the Islamic perspective, on the other hand, a concept of poverty cannot be measured just from the material aspect and should include the spiritual aspect. Hence, the children's welfare is crucial during the current time despite the monthly financial support given to the school student by the Kelantan Department of Education and Kelantan Islamic Foundation. For the primary school category, the financial support given is at RM80 per month while for the secondary school category (Form 1- Form 5 student), RM120 per month is given and RM180 is given to Form 6 students. According to MAIK (Majlis Agama Islam Kelantan) data, there are 1027 receivers of the Tengku Anis scholarship until December 2019. All applications for these financial aids must be made through the Kelantan Department of Education and the Kelantan Islamic Foundation.

Furthermore, according to UNICEF, a high nutrition food provision is one main problem in Malaysia. It is recorded that one in five children experience stunted growth and one in ten experiencing low body weight. Low nutrient in food resource is one of the denied 
rights. The research found that low body weight, stunted growth, and skinny problems have been the ongoing issue among children under 5 years old two times more than the average rate in Kuala Lumpur. On the other hand, the overweight problem, reaches almost six times more (32\%) than the average rate $(4 \%)$ in Kuala Lumpur. Moreover, the highest percentage of stunted growth in children recorded in 2016 was Kelantan with $34 \%$. Compared to other countries with the same KDNK per capita as Malaysia, the bodyweight of children in Malaysia shows a much higher rate. For example, almost $13 \%$ of children in Malaysia whom 5-19 years old are experiencing obesity which this percentage recorded to be higher than Hungary (11\%), Turki (10\%), and Polland $(9 \%)$. The percentage of stunted growth in children in Malaysia, is more severe than Ghana even though the KDNK per capita of Malaysia is six times higher. In the wealthiest district of Malaysia, Putrajaya, almost one of four children experiencing stunted growth is higher than the national average rate.

Based on UNICEF Malaysia's report, children from the most improverished state in Kelantan, have recorded a severe rate compared to the children in low-income countries such as Zimbabwe and Swaziland. Therefore, this research is very significant because Kelantan was also affected due to the pandemic outbreak. Therefore, this study focuses on the children who are populating Kelantan and reside in the highest infection rate district or the red zone. However, Malaysia has been provided various established programs to be carried out by the related agencies to combat the poverty problem among the B40. One of the initiatives is the education aspect such as a oneoff financial aid program and private pre-school fee support for household income less than RM3000 by the Ministry of Education. Not only that, financial support worth RM100 per month for 7 years old to 17 years old children, with an additional RM150 per month for a household with income per capita under RM300 and RM75 for household income per capita under RM500. These initiatives have been carried out in the normal situation and are this aid could help the children during the Covid-19 outbreak? In the aspect of the resource, The Ministry of Education and Ministry of Health also employs a food charity program for the student from low-income families, a free milk program and recovery program for six months to six years old children who experience lack of nutrition. This situation has been happening within the normal situation and it is highly concern during the Covid-19 outbreak because it could be affecting the children badly. However, this program was allocated for the student from household income lower than RM3000 and group B40. Before pandemic, one of the ministries initiatives is the distribution of free food at school worth RM2.50 per person in Peninsular Malaysia and RM3.00 per person in Sabah and Sarawak and two cartons of chocolate milk $(200 \mathrm{ml})$ are provided twice a week and it should be continued due to the pendemic. The government body also participates in the initiatives made for people's health, such as, the National Immunization Program lauch by the Ministry of Health, which provides free immunization for any preventable diseases. From the aspect of children welfare, the Ministry of Women, Family, and Community Development has allocated allowance worth RM100 until RM450 per month for children under 18 years old whose family consists of more than four kids. Therefore, we can observe a serious concern from the government body towards the children and, hopefully, the Covid-19 outbreak will not be affecting these children negatively. 


\subsection{Conclusion}

Children Protection Policy (Children Act 2001) is a type of policy that consists of statements related to children's protection principles in line with the Convention of Children Rights. This policy focuses on advocation, prevention, support system, and research and development to serve the one purpose: protecting the children. There are three Ministries that are involved in this policy; - (1) Ministry of Health, (2) Ministry of Education, ad (3) Ministry of Women, Family and Community Development. Besides, through this study, several policy implications and suggestions can be established such as (1) providing a guarantee in social protection towards the children during the Covid-19 outbreak and (2) Getting insight into the factors causing poverty among B40 children from various perspectives as well as acknowledging any possible injustice that might happen. The Children Protection Policy has been employed to ensure every child is provided with care and protection against neglect, abuse, violent acts, and exploitation. This policy has also been a catalyst towards awareness and commitments from all parties including all community members in protecting the children, especially during the Covid-19 outbreak.

Moreover, we need to understand and know the needs of B40 children from the aspects of education, food, health, and welfare during the outbreak and its effects on the involved children. Therefore, an awareness of society is significant so we could view this shortcoming from a positive side. Make use of this RMO period to be more productive, have a chance to amending and strengthen the relationship among family members, do any fun activities, and always look for wisdom through the difficulties and unfortunate events in hoping that the society is safe from COVID-19 outbreak.

\section{References}

Begum, S. S., Deng, Q., \& Gustafsson, B. (2012). Economic growth and child poverty reduction in Bangladesh and China. Journal of Asian Economics, 23(1), 73-85. doi:10.1016/j.asieco.2011.10.001.

Camfield , L., Streuli, N.\& Woodhead, M. (2008). Children's well-being in contexts of poverty: approaches to research, monitoring and participation. Young Lives Technical Note. 12, August.

Cuesta, L., \& Meyer, D. R. (2018). Child poverty and child support policy: A comparative analysis of Colombia and the United States. Children and Youth Services Review, 93, 143-153. doi:10.1016/j.childyouth.2018.07.013

Dorabawila, V., DuMont, K., \& Mitchell-Herzfeld, S. (2012). A method for estimating child poverty rates, projections for the short-term and the relationship between child poverty and child are subsidy receipt at the county level. Children and Youth Services Review, 34(2), 466-473. doi:10.1016/j.childyouth.2011.12.005

Ge, T., \& Wang, L. (2019). Multidimensional child poverty, social relationships and academic achievement of children in poor rural areas of China. Children and Youth Services Review. doi:10.1016/j.childyouth.2019.06.007. 
González, L., Estarlich, M., Murcia, M., Larrañaga, I., Barreto, F. B., Santa-Marina, L.,Rebagliato, M. (2020). Risk of child poverty and social exclusion in two Spanish regions: social and family determinants. Gaceta Sanitaria. doi:10.1016/j.gaceta.2019.11.002.

Haq, R. \& Zia, U. (2013). Multidimension wellbeing: an index of quality of life in a developing economy. Social Indicators Research 86. Doi: 10.1007/s11205-012-0186-6.

Ingutia, R., Rezitis, A. N., \& Sumelius, J. (2020). Child poverty, status of rural women and education in sub Saharan Africa. Children and Youth Services Review, 111, 104869. doi:10.1016/j.childyouth.2020.104869.

Laporan Kemiskinan Kanak-kanak Bandar, UNICEF (2017), Cadangan Dasar Program sedia ada, Kaji Selidik Kekurangan Zat Makanan, Kaji Selidik Pendapatan, Bantuan dan simpanan.

Main, G. (2017). Child poverty and subjective well-being: The impact of children's perceptions of fairness and involvement in intra-household sharing. Children and Youth Services Review. doi:10.1016/j.childyouth.2017.06.031

Majlis Agama Islam dan Adab Istiadat Melayu, (2019). Laporan Khas Terimaan dan Perbelanjaan MAIK, http://www.e maik.my/v2/index.php/ms/laporan-terimaan-danbelanjawan.

Musiwa, A. S. (2019). Multidimensional child poverty in Zimbabwe: Extent, risk patterns and implications for policy, practice and research. Children and Youth Services Review, 104, 104398. doi:10.1016/j.childyouth.2019.104398

Nor Ayuni Mohamad Zulkifli et al, (2018), Persepsi Golongan Miskin Terhadap Kemiskinan Dan Implikasinya Dalam Merealisasi Pembangunan Nilai Islam: Kajian Terhadap Penduduk Miskin Bandar Kota Bharu, Kelantan. Persidangan Kebangsaan Ekonomi Malaysia ke- 13 Bangi, Selangor, Malaysia.

Nor Fazlina Abdul Rahim,(2020), COVID-19: MB Kelantan Umum RM300 Kepada Keluarga Mangsa. Berita Harian Online, nfazlina@nstp.com.my.

Portal Jabatan Kebajikan Masyarakat, Dasar Perlindungan Kanak-kanak Negara 2001,http://www.jkm.gov.my

Qi, D., \& Wu, Y. (2015). A multidimensional child poverty index in China. Children and Youth Services Review, 57, 159-170. doi:10.1016/j.childyouth.2015.08.011

Statham J \& Chase E. (2010). Chidhood Wellbeing: A Brief Review.Briefing paper 1, August, Chidhood Wellbeing Research Centre. Retrieved from http://www.cwrc.ac.uk/documents/CW_Briefing_paper.pdf 